Oral Tradition, 2/2-3 (1987): 573-615

\title{
The Living Ballad in Brazil: Two Performances
}

\section{Judith Seeger}

Many approaches have been devised to study the elusive art form known as the oral traditional ballad, to try to reach an understanding of the interplay between memory and creativity in its transmission from one generation to another over several centuries. In this paper I will add yet another approach: a close analysis of two oral performances I recorded in rural Brazil in 1978.

Since an oral traditional ballad in order to survive must be intelligible, meaningful to its listeners, and aesthetically pleasing, it is evident that problems will be raised by performing ballads of medieval Iberian origin in a contemporary rural Brazilian context. Some of these problems are linguistic, brought about by evolution of the spoken language. Others arise from changing socio-economic and historical conditions. Attempts by singers to resolve these problems lead sometimes to inspired innovations and sometimes to strained accommodation between the received text and the singer's desire to bring it to life for contemporary listeners. At every moment in each variant the desire to maintain tradition confronts the necessity for innovation. Sometimes tradition takes precedence; sometimes innovation. A ballad requires both to survive. Each rendering of a living ballad is the sum of the varying resolutions of its vital conflicts.

It was in order to observe such conflicts and their resolutions that during 1977 and 1978 I spent a year living in the coastal town of Conceição da Barra, Esprito Santo, Brazil, searching for oral traditional ballads in performance contexts. ${ }^{1}$ Conceição da Barra is the center of a rural region settled by fishermen and small farmers, which has had a relatively stable population for most of its history. I chose to work there after reading and talking with Brazilian ballad scholars including Bráulio do Nascimento and 
Guilherme Santos Neves. Neves, though he was far from sanguine about the vitality of the oral traditional ballad, had collected ballads in the region; so I knew a tradition had existed there.

My field project grew from the conviction that a legitimate and interesting way to approach questions of creativity, transmission, aesthetics, and meaning in oral traditional balladry would be to seek out the singers to discover how, when, where, and to whom they performed. My specific goal was to hear ballads performed for others, not for my microphone alone. I knew this approach would preclude collecting a large corpus of variants, but I expected the extratextual information obtained would compensate for the small number of texts. By remaining in one place over an extended period, I would give myself time to learn about the singers and listeners, their way of life and the entire oral tradition they shared. From the vantage of this general context I wanted to observe how an individual in a given performance intellectually and artistically interprets a traditional piece to the satisfaction of all involved.

In my fieldwork I confronted the problems faced by any collector of oral traditional ballads. Experience confirmed the warning that asking for a romance would lead to nothing. The word, which in Brazil denotes a narrative song, a narrative poem written for the literatura de cordel, and a novel, had absolutely no eliciting value. Incipits (the first lines of a ballad) and plot synopses were scarcely more effective at first, though they later led to recordings of $O$ cego (The Blind Man) and Juliana e dom Jorge (Juliana and Don Jorge, known to collectors of Spanish ballads as El veneno de Moriana). When exhaustive searching for ballads proved nearly fruitless, I turned my attention to the local storytelling tradition. This tradition, though it too is less vital than it once was, continued to exist around Conceição da Barra and to involve both sexes and all ages. In sessions attended by a number of individuals I hoped to gain contextual and performance information that would be applicable to a discussion of the apparently defunct ballad tradition.

I began with the help of local people to organize storytelling sessions of the type Kenneth Goldstein in his book A Guide for Fieldworkers in Folklore has called "induced-natural."2 Such sessions, though convened by me, were modeled on what people had told me about traditional events. Since the ideal of effacing myself and hiding my recording equipment was clearly impossible, 
the sessions could never be entirely unselfconscious. Their quality as traditional events varied, but at some point during the best of them tellers would invariably turn away from the microphone to interact with living people - verbally by inserting them into the story, visually by eye contact, sometimes by touch. The unresponsive microphone would lose its initial appeal, and the session would take on a dynamic of its own in which individuals would swap stories and anecdotes, each one suggesting another.

As time passed I found myself working almost exclusively with the poorer inhabitants of the region, who were richer in oral traditions. Some sessions were held in houses in the dark back streets of Conceição da Barra. Some were convened on isolated small farms. Most gatherings took place in the nearby settlement of Itaunas. To correspond to the needs of the participants, almost all the sessions were held on Saturday nights. The get-togethers were relegated to nighttime by local custom, reinforced by the belief, particularly prominent among the men, than anyone who told stories during the day would grow a tail. The few daytime sessions I recorded involved women and a few men who allowed themselves to be convinced that it was all right to tell stories during the day on weekends. One of the best male tellers, however, retorted to some women who insisted nothing would happen to him if he told stories during the day that it was all right for them because they could hide their tails under their skirts. Saturday was the chosen night because it was the only time people were not faced with having to rise early to work the next morning.

Twice I was surprised when within the context of storytelling sessions unsolicited ballads were performed. The bulk of the rest of this paper will be devoted to describing the settings and analyzing those two spontaneous performances, both versions of the ballad El conde Claros de Montalbán (Count Claros of Montalbán), whose first published texts date from sixteenth-century Spain. ${ }^{3}$ One woman performed the version known to collectors of Hispanic ballads as Conde Claros en hábito de fraile (Count Claros in Monk's Attire), the other Conde Claros y la infanta (Count Claros and the Princess). In my analyses I will comment on musical, linguistic, social, and aesthetic characteristics of each performance.

In considering the music of the ballad, I am departing from the mainstream tradition of ballad studies. Musicological studies of Hispanic ballads do exist, notably those of Israel Katz. ${ }^{4}$ 
Nevertheless, scholars in the field have never examined relationships between the text and the tune of a ballad, and most published ballad variants in any tradition are not accompanied by their melodies. Though it is true that traditional texts may be sung to different tunes and that the same tune may be adapted to different texts, it does not follow that searching for relationships between a given text and its tune is in vain. The typical ballad melody has distinctive generic characteristics, two of which are particularly significant in terms of the text. These are its shortness and its internal organization.

The shortness of the ballad melody has important implications. A ballad tune is typically a four-phrase unit to which are sung texts whose lengths, though they vary, always exceed four phrases. An obvious consequence of the wedding of brief tune and lengthy tale is the necessity of repeating the melody. The ballad scholar and musicologist, Bertrand Bronson, has commented suggestively on what he perceived to be a fundamental conflict between the narrative ballad and its essentially lyric melodic vehicle:

Upon reflection, we must perceive that the very idea of narrative, or progress from point to point in a story, is inimical to its statement in identical units of simple melody, repeated as many times as need requires. The melodic form, an integrated succession of a given number of short phrases, has powerfully imposed itself on the verse form to mutual advantages; but the inherent demands of narrative [Bronson's emphasis] songs are for a freer and more dramatic vehicle; . . . clearly, the traditional ballad music operates against the narrative effect and acts to reinforce the level impassivity of the characteristic style. And this is a source of its peculiar power. Although it intensifies the emotional (and lyric) effect of the words as they pass, it deindividualizes and objectifies their stated content. It regularizes and levels out the hills and valleys of narrative interest and reduces the varying speeds of travel to its own constant pace. (1979:128-29)

Of course the description of ballad narrative as "progress from point to point in a story" is not strictly accurate. As Bronson surely knew but chose not to emphasize here, near repetition, 
called parallelism, is a fundamental device of ballad organization on the structural and verbal levels as well as on the musical level. For example, the often-doubled questions posed by the father to his pregnant daughter in the Hispanic ballad known as the Mal encanto (Evil Spell) illustrate verbal and structural parallelism, as does the often-tripled test of the princess in Count Claros in Monk's Attire. In either case, a single question or proposition would suffice to advance the narrative. The predominance of dual and triple figures in these and other ballads shows that parallelism is an important feature of the genre. There is a difference between voluntary parallelism and obligatory, essentially unaltered melodic repetition. Nevertheless, the gulf between the narrative character of the ballad text and the repetitive nature of its musical realization is not so wide as Bronson might lead us to believe. On the contrary, the repetitive structure of the music, with all the power Bronson ascribes to it, reinforces a fundamental characteristic of the organization of the text. A ballad, even stripped of its tune, is not simply a linear narrative, but rather a narrative structured in a particular and characteristic way.

The second point to be considered with regard to the ballad tune is its internal organization. A typical ballad melody has an identifiable structure: four musical phrases which reach a mid-cadence at the end of the second phrase and terminate with a final cadence at the end of the fourth. Roger Abrahams and George Foss describe the traditional tune type of the Anglo-American ballad thus:

As the verbal rhyme brings a sense of repose and finality to the stanza, so are the melodic cadences arranged to produce tension at the mid-cadence and repose at the final cadence. This is done musically by placing a tone other than the final at the mid-cadence, the final tone representing to the traditional singer the tone of greatest repose within the scale. $(1968: 161)$

It will immediately be objected that the Hispanic ballad does not traditionally employ stanzaic verbal rhyme. And, in fact, the unchanging assonance characteristic of the Hispanic tradition does seem to allow a degree of melodic freedom not available to the Anglo-American ballad. If we letter each phrase, the generic ballad tune can be represented by $A B C D$. Repetition of the final two phrases, though not the rule in Hispanic balladry, is by no 
means unknown. Unlike in the Anglo-American ballad, there is no verbal restraint against singing a strophe representable by $A B C D C D$, or some variation thereof, if the singer feels that the extra verses complete a thought rather than begin a new melodic and verbal unit. This phenomenon has been documented for the Brazilian ballad by Jackson da Silva Lima and Antônio Lopes, and I have examples of it in a ballad corpus I collected in northern Spain. ${ }^{5}$

Such flexibility, however, is not usually needed. The typical sung Hispanic ballad, like its Anglo-American congener, is sung to a four-phrase tune and thus expresses the repeated pattern of tension resolving in at least temporary repose that is built into the music. Close examination of ballad texts reveals that the musical relationship between the mid-cadence and the final cadence reinforces a hierarchical relationship between two lines of verse (or two units of thought) which may be described as unfinished leading (at least temporarily) to finished. Though this relationship may not be immediately evident in written representation of a ballad that does not employ strophic rhyme, it is nonetheless an important element of the sung (the heard) ballad.

Indeed, the strophic character of a ballad melody seems to be an important influence on the organization of the text. Both ballad variants to be discussed in this paper adhere to traditional assonance schemes, though they in fact employ rhyme. Yet their organization is clearly stanzaic. Each group of four hemistichs is a unit, and is regarded as such by the singer. The prose intercalations that introduce each fourhemistich unit are the most obvious indication of strophic division. But even if they were removed, the unity of each group (hereafter called stanza) would be evident. The two verse lines that comprise each fourphrase stanza are always related to each other in terms of the hierarchy "unfinished $\rightarrow$ finished" that corresponds to the musical organization "tension $\rightarrow$ repose." A stanza may consist, for example, of a question and its answer, a statement and its elaboration, a sentence opened by a dependent clause, two parallel verse lines, or a description of a scene in which the second verse is consequent to the first. Though the specific intra-stanzaic relationships differ, each stanza is structurally a unit. The hierarchical nature of this unity - which replicates on the level of the stanza the hierarchical relationship between hemistichs-coincides with the organization of the ballad melody. 
The variants to be discussed here present the particular renderings of two traditional performers. The melding of text with tune is one level on which we shall observe the singers' craft. Each segment of text will be printed separately and discussed before moving on to the next. Segments that are particularly interesting musically are accompanied by musical transcriptions. The transcriptions, written using the conventions of writing Western erudite music, are not perfect representations of what was sung. Even inexact representations, however, demonstrate the reciprocal influences between text and tune that interest us here. ${ }^{6}$

\section{Count Claros in Monk's Attire: Dona Branca}

I do not know what prompted Maria da Conceição, a fortytwo-year-old resident of the town of Itaunas, Espírito Santo, to sing the story of Count Claros in Monk's Attire. It was Saturday night, May 20, 1978. I had met Dona Conceição three months earlier, presented by her seventy-three-year-old mother, who had first invited me to Itaunas after approaching me on the street one day in Conceição da Barra and introducing herself. The two women were much alike. Short, swarthy, and stoutly-built, they were outgoing and cheerful. Both had welcomed me into their homes and had told me some of the stories they remembered from the time when they used to pass Sunday afternoons and long evenings trading tales with others. I had tried in every way I could imagine to discover whether they knew any ballads, to no avail. Since both women were clearly trying out of sheer good will to help me, I assumed they knew no ballads.

That evening we were in a small house at a storytelling session very much like others held in the town. Itaunas was at the time a settlement of some three hundred people linked to Conceição da Barra by a narrow dirt road, which regularly became impassable during and after heavy rains. The town was separated from the sea by the Itaunas River, known locally as the River of the Poor because it provided abundant fish for people who could not afford to buy meat. The original town, located on the seaward bank of the river, had been literally buried by sand. All that remained of it were a few nearly-interred trees and a mast stuck in the towering dunes to mark the place where the church perhaps still stood. The inhabitants of the new Itaunas were those who had decided not to leave the region when the fine sand - carried by the prevailing northeast winds and no longer impeded by the 
receding forest - gradually invaded and then covered their homes. One reason oral tradition survived in Itaunas was that it had electricity for only three hours a night, when there was enough fuel to run the town generator.

Our host for most Itaunas storytelling sessions was a man named Pulquério Aldo dos Santos, known to all as Seu Antero. He had built himself and his family a small house and adjacent store where he sold inexpensive sugarcane liquor and cups of weak but sweet coffee as well as other assorted goods: bananas, coconuts, home-made sweets, beer, soft drinks, cheese. A typical storytelling session in Seu Antero's living room would begin after nightfall. I would be seated on the bed that served as a couch when no one was sleeping. The rest of the furniture consisted of a low bookcase on which were arranged school books and knick-knacks; rough wooden benches lining two walls, brought in especially for the session; a clay water filter and glass high on a corner shelf; and on a square table at one end of the bed/couch a small candlelit shrine to Saint Benedict the Moor ornamented with plastic flowers, rosaries, medals, and ribbons. The whitewashed walls were decorated with colorful pictures cut from magazines.

The front doorway and glassless window, its shutter left open, would be crowded with people of all ages coming to see what was going on. Passage through the back doorway, which led to the bedroom and outside to the kitchen behind the store, was reserved for the family. Seu Antero's wife would appear in that doorway to listen to the proceedings when she was not needed in the kitchen or the store. Seu Antero himself would disappear through the doorway from time to time and return fortified by a drink of sugarcane liquor. Occasionally he passed a glass of liquor to adult men sitting on the benches, "to help warm up their memories." Women stood leaning against the walls and sat on the floor with children beside them and in their laps. Older boys scaled and balanced on the top of the interior wall behind me, which, as in most rural Brazilian homes, did not reach the ceiling.

The session of May 20, except for the unexpected appearance of Count Clams, was not one of the better ones. A jongo, the local circle dance, was being held nearby. Drumming and singing could be heard in the background, and there was an extraordinary amount of coming and going from one event to the other. Our host, a leading singer and drummer as well as storyteller, was distracted. The call of the drums was finally too much for us; the 
session dissolved earlier than usual, and we all went to join the dance.

Dona Conceição began to perform abruptly, after complaining about the noise of people entering and leaving, stepping on the feet and hands of those seated on the floor, begging pardon. She was sitting on the floor facing me near the center of the room. Spectators were as usual crowding into the open doorway and leaning on the windowsill. Dona Conceigao spoke and sang rapidly, but clearly, in her usual manner. During the first segment of the ballad, until she recounted the midwife's verdict on Dona Branca's condition, there was talking in the background as new arrivals searched for places to sit or stand. Thereafter the audience was listening and silent except for occasional murmurs, laughter, and Seu Antero's comments on the story. His remarks are noted in brackets in the following transcription.

Dona Conceição began:

"Disse que tinha uma moça, que ela ficou gorda em casa."

(It was said that there was a girl, who "got fat" at home.)

In the style that has become typical of many Brazilian ballads she begins with a prose introduction. The prose, as well as the storytelling performance context, indicate that she regards the ballad primarily as a tale. Her style of presentation is appropriate to a piece performed for entertaining a group. It is distinctly not that of a lullaby, for example, or a song sung to lighten solitary work.

I recorded many stories beginning with the formula "disse que ... "In the region of Conceição da Barra it was more popular than the more formal "era uma vez ... "The expression "dizem que ...," is often used in everyday conversation to absolve the teller of a fantastic story from responsibility for the truth of repeated hearsay. It would precede the recounting of abnormal or inexplicable happenings - werewolves, for example, or other strange beings said to roam the surrounding eucalyptus forests. Pronounced emphatically it would indicate incredulity on the part of the teller, who, nevertheless, was not willing to go so far as to deny out of hand the verity of what was being told. The conventional "disse que" has a parallel effect in formal oral narrative. Singular, but impersonal, preterite, it is a distancing device. It separates what is to follow from ordinary discourse, promising that the narrative will be interesting, structured, and 
possibly incredible. The narrator, merely passing it on, assumes no responsibility but to tell it well.

The rest of the opening phrase puts the central transgression in a nutshell. The expression "ficou gorda" is a vernacular euphemism for becoming pregnant. The word gorda, phonetically close to the forbidden grávida, suggests the condition without actually saying it. In popular speech, people of northern Espírito Santo as in much of Brazil tend to reduce trisyllabic words whose accent falls on the first syllable to two syllables. Sábado, for example, typically becomes sabo; lámpada becomes lampa. Metathesis of an " $\mathrm{r}$ " and its preceding or following vowel is also common. And the word gorda, in addition to being nearly derivable from grávida by the rules of vernacular sound change alone, has the further advantage of pointing out the salient characteristic of the pregnant woman's changing figure. Saying that the girl became pregnant "em casa" means that she was living in her natal house at the time. She was not married.

“Entao' o pai dela falou assim . . . cantou assim

(So her father said thus ... sang thus:)

The phrase is incomplete, leading into the sung dialogue that is to follow. Dona Conceição hesitates as the style of delivery is about to pass from that of spoken narrative to that of sung ballad. She seems suddenly to be caught short by the significance of her own words. Obviously the father did not sing to his daughter. Yet Dona Conceição is going to sing his question. She is briefly undecided, then resolves to use the verb that really describes what is going to happen. For a moment the narrator is more conscious of her manner of recounting the story than of what is being recounted. She thus prepares the audience for the change from speaking to singing.

$=144$ (very irregular)

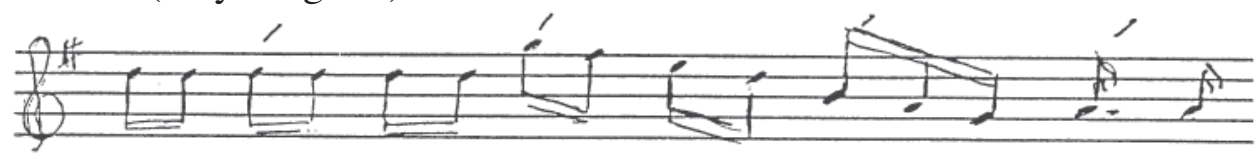

2-- O que ten-des mi-nha fi-lha que 'tas tão a-ma-re-la?

(What's the matter, my daughter? Why are you so yellow?)

The first question is typical of Count Claros in Monk's Attire variants that begin with the Evil Spell, as do most Brazilian texts. 
The second is not. I have discussed its Brazilian origin and significance in my article "Notes on Traditional Creativity: Examples of Innovation in Two Brazilian Romances." Suffice it to say here that it is an innovation with respect to the traditional language of the ballad.

"Aí, ela falou p'r'o pai assim:"

(So she said to her father thus:)

This prose intercalation, like most of those that follow, identifies another speaker. Traditionally singers who regard ballads as songs have felt no need to indicate differing speakers. There is a strong tendency in contemporary Brazil, however, to identify them unless actual singers alternate as they do in dramatic representations (these days usually by children) of such ballads as Juliana and Don Jorge and The Blind Man, or unless the ballad is sung as a lullaby or to accompany work, situations in which the absence of a critical audience precludes the need for clarification.

The language of the prose segments is always colloquial. The "aî" that introduces this phrase is a typical discourse marker in informal narrative style. Dona Conceição uses it to begin almost every prose segment. Here, as in the following intercalations, her verb indicates speech, not song. Now that she has introduced the switch to song once and become involved in her story, she no longer hesitates over the discrepancy between her singing and the character's saying.

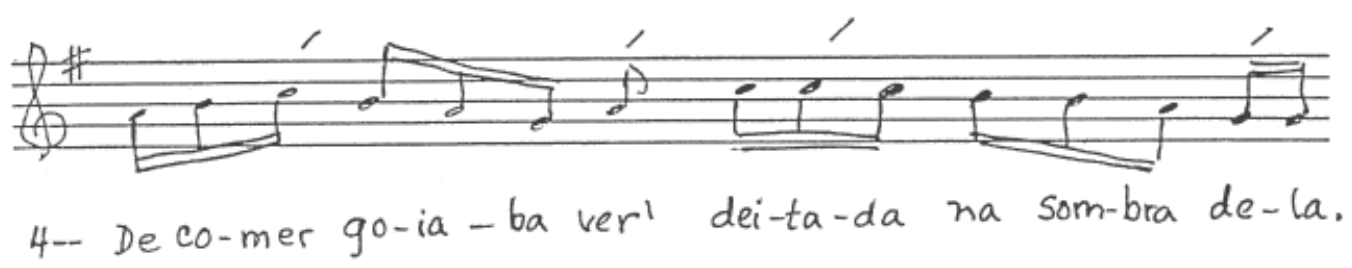

(It's from eating green guavas, lying in the shade of the tree.)

The young woman's most common excuse in the Evil Spell is that drinking cold water has caused the change in her complexion. Dona Conceição's green guavas, in contrast, are unknown to published texts. As I have already discussed these unusual lines in the work cited above, I will not linger over them here. The music, however, merits a closer look.

Like any traditional singer, Dona Conceição sang in a natural voice, choosing a comfortable range. Though I have transcribed the piece to end on the note $\mathrm{G}$ above middle $\mathrm{C}$ in accordance with 
norms of ballad transcription, each stanza actually terminates about a quarter tone above $\mathrm{F} \#$ below middle $\mathrm{C}$. The melody rises to its highest pitch in the first hemistich where key words are often located: "filha" in hemistichs 1 and 5, "pal" in 9 and 13, "carta," "beijo," "abraço" in later hemistichs. The mid-cadence falls on the second, a definite point of tension in the major scale of this tune. The third phrase, nearly recapitulating the preceding one, maintains the tension by ending on the same note as the mid-cadence. The last phrase is a four-step cadence descending to the final, which is also the tonic of the scale.

Though Dona Conceição did not noticeably employ either volume or tone quality to heighten her delivery, she did, without departing from the general contour of the received tune, manipulate pitch distribution in accordance with the demands of the text. In the third phrase of the tune, for example, the first pulse always falls on the highest note (the $\mathrm{C}$ above middle $\mathrm{C}$ in my transcription). Usually two leading tones precede it:

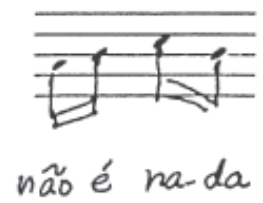

But the pitch pattern may be altered to correspond to another stress pattern, as, for example in hemistich 15:

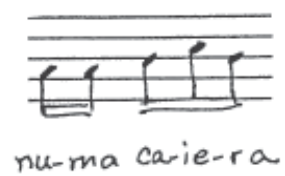

The same technique may be observed in the fourth phrase, where the tonal pattern of hemistichs 8 and 28 :

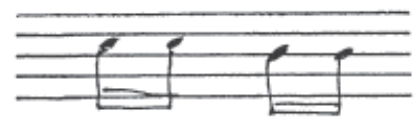


differs from that of the others:

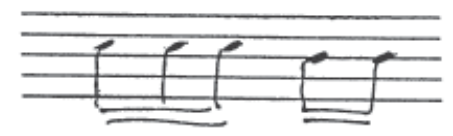

The first stress of this phrase normally falls on the note B. Exceptions are found in the first and seventh stanzas, in which Dona Conceição elids the last word of the third hemistich to the first word of the fourth, and the stress falls on the second C. Similar variations may be observed throughout the ballad. They demonstrate how changing tonal distribution molds the music to fit the words.

I have not barred the musical transcriptions, since barring would indicate metrical rigidity that does not exist here. Though the four phrases, each comprising eight beats, are in principle of equal length, they in fact differ slightly. The second and fourth phrases are as a rule longer than the first and third because their last notes, corresponding to the mid and final cadences, are briefly extended. Additionally, timing with a stopwatch shows that phrase duration is not fixed. Thus, although the metronomic tempo indication suggests the speed of the singing, it does not describe accurately the temp of even two contiguous phrases. Rather, Dona Conceição consistently departs from the tempo and returns to it. In those stanzas where the rhyme scheme is á-a for example, the first " $a$ " is lengthened while the second is scarcely touched. The word "pai" in hemistichs 9 and 13 is briefly extended, thereby receiving a rhythmic accent that reinforces the importance of the word. The subtlety of most of Dona Conceição rhythmic alterations, perceived as metrical irregularity, defies representation in words or transcription.

Each phrase has two principal pulses, indicated with accents above the musical staff. Varying locations of these pulses within the metric scheme of the phrases are determined by the interaction of text with melody. There are phrases (notably hemistichs 39 and 43: "Boca/ corpo que dom Carlos beija/abraça," where the first musical pulse falls on the word "que") in which melodic stress cannot be made to coincide with verbal stress. Such moments, common in balladry and discussed by Charles Seeger in his study (1977) of the Anglo-American ballad Barbara Allan, create a 
counterpoint between words and music, which enriches the texture of the piece by calling attention to the occasionally uneasy accommodation between words and music. Moments where musical and verbal stress do not coincide are probably more common and less significant in Hispanic than in Anglo-American balladry because English poetic meter is based on stress and Hispanic meter is based on syllable count. Yet they are striking here, since it is clear that Dona Conceição makes an effort to have the stress of her music and words coincide as much as possible.

“Aí o pai foi, falou assim

(So her father went and said thus:)

The spoken interruption takes the form adopted by most of the succeeding intercalations: "Aí [ . . ] foi, falou assim " The phrase, though not inverse, is formulaic in this variant of the ballad. It may be expanded or contracted, but its structure is always the same.

$6 \quad$ “- 0 que tendes, minha filha, que "tas tão desmudada?

8 -Não é nada, senhor pai, é a saia mal talhada."

(What's the matter, my daughter? Why are you so changed? It's nothing, father sir. It's my badly tailored skirt.)

This stanza adopts the characteristic assonance and the second most common excuse of the Evil Spell. "Desmudada" is a regional pronunciation of the rarely used adjective demudada. The young woman blames her badly-tailored skirt for her altered appearance in many variants of this ballad from Brazil, Spain, Portugal, and Catalonia, as well as in its tragic Hungarian counterpart, sometimes called Barbara Angoli, and the German Ritter und Magd and Schwabentöchterlein. The motif of the shortened skirt, which also appears in the sixteenth-century Spanish Tiempo es, el caballero seems to float freely within the ballad tradition of the dishonored maiden.

"Aí o pal dela mandou fazer uma roupa diferente ... . Aí mandou chamar a parteira. A parteira falou assim: "Dona Branca não sente febre nem 'defruço'. Olhe o bucho!"

(Then her father had some different clothes made .... Then he had the midwife called. The midwife said: "Dona Branca doesn't have fever or the flu. Look at her gut!") 
Usually the excuse of the ill-tailored skirt prepares for a neat reversal in which tailors summoned by the father point out to him that the young woman is responsible for the change in the skirt rather than the other way around as she has claimed. That segment of verse has been either forgotten or intentionally omitted here. The pause after the first sentence replaces stating of the obvious: that different clothing will make no difference. The father calls the midwife.

Dona Conceição had evidently memorized the midwife's short speech. Months later when I asked her the meaning of the word I have spelled "defruço" she said, and others confirmed, that it meant what Brazilians normally call gripe, or flu. The word defruço is probably derived from defluxo, defined as a head cold. Its phonetic transformation follows standard unwritten rules. In Brazilian vernacular " 1 " is often replaced by "r." Pronunciation of intervocalic " $x$ " is not fixed: it may sound as "ks," "z," "s," or ash." Defruço is a euphemism whose creation was motivated by fear. It was used by older people, Dona Conceição explained, to avoid naming the dread influenza for fear of summoning it. After defining the word for me, Dona Conceição repeated the midwife's declaration word for word, laughing heartily. The diagnosis is decidedly coarse. Using the word "bucho," which usually denotes the stomach of an animal, to refer to the womb of a young woman is unflatteringly suggestive.

"Aí foi, o pai dela foi, falou assim:

(So he went, her father went and said thus:)

10 -Filha que faz iss' ao pai merece ser degolada,

12 cõ'a navalha de arpaõ, um arpaõ bem amolada."

(A daughter who does that to her father deserves to be beheaded, with the blade of a harpoon, a well sharpened harpoon.)

The father, typically, is outraged at what his daughter has done to him. His suggestion that her head be cut off (or her throat be slit), however, is unknown to published texts of Count Claros in Monk's Attire, where immolation is always the selected method of execution. The choice of a harpoon as the weapon to carry out the beheading gives the rendering a local flavor. Much of the Brazilian coast, including northern Espírito Santo, was once whaling country.

The fourth hemistich of this stanza includes the first of three 
cases in this variant in which demands of the rhyme scheme supersede grammatical rules. The word "amolada" modifies "arpão " But arpão is masculine, so the concording adjective would be amolado. At a moment of conflict the singer chooses to sing "amolada" to rhyme with "degolada."

"Aí o irmão dela foi, falou assim:

(So her brother went and said thus:)

14 -Filha que faz iss' ao pai merece ser requeimada

16 numa caieira de fogo, corn lenha bem atiçada “

(A daughter who does that to her father deserves to be thoroughly

burned in an oven of clay tiles, with well lit wood.)

I have seen no other variant of the Count Claros beginning with the Evil Spell in which a brother is introduced. In this respect Dona Conceição's rendering recalls the Portuguese texts of Count Claros in Monk's Attire in which the wayward woman's brothers debate forms of execution. The intervention of the brother here probably stems from the incorporation of the previous anomalous stanza, rather than from influence by those variants, which are otherwise quite distinct. Need for identifying a second speaker arises from the presentation of alternative methods of execution. Since the brothers of an unmarried woman traditionally share with her father responsibility for her sexual honor, a brother is a logical interlocutor at this point.

The "caieira" is either an oven for baking lye or a kiln made of the clay tiles it is to fire. Its appearance, reinforced by the emphatic "requeimada," meaning well or excessively burned, suggests that Dona Branca in this variant is not merely to be scorched on a pyre; she is to be baked to a crisp.

"Aí ela foi, pegou a passear na varanda, chorando"

(So she went and started walking on the balcony, crying.)

This prose intercalation, like that revealing the truth about Dona Branca's condition, condenses a narrative juncture which in the tradition of the Iberian Peninsula appears in verse. It rarely appears in any form in the Brazilian tradition, where Dona Branca's wish for a messenger usually follows directly upon her father's sentence. Dona Conceição describes her as crying, a necessary modifier to show that her action, "passear na varanda," is not the pleasurable stroll it might otherwise appear. The sentence has narrative, visual, and dramatic value. It locates Dona 
Branca on the marginal territory from which she will summon the messenger, as well as describing in concrete ballad style, despite the prose, her movement and emotional state.

"Aí ela foi, falou assim:

(So she went and said thus:)

18 - Se tivesse um criado que fizesse meu mandar,

20 eu mandava uma carte a Carlos de Montevar.

(If I had a servant who would do my bidding,

I would send a letter to Carlos de Montevar.)

O nome do rapaz chamava-se Carlos de Montevar.'

(The name of the fellow was Carlos de Montevar.

The characteristic -á assonance of the Count Claros begins in hemistich 18, though not without some violence to the language, for "mandar" makes an awkward noun in this context. Claros' name in the ballad tradition can take many forms. The name in this rendering is remarkably close to the original. Claros, where it has been retained, has universally become Carlos. The surname Montevar fits the -ar rhyme scheme, which will be maintained from now on.

Hemistich 20, almost halfway through the ballad, is the first to mention the male protagonist. Such delay is typical of Count Claros variants that begin with the Evil Spell, and is to some extent a consequence of the joining of the two ballads. Though the plan in hemistichs 13-16 to burn the misbehaving daughter strongly hints at imminent transition to Count Claros in Monk's Attire, the ballad at that point is still within the assonance scheme of the Evil Spell. The transformation to the dominant ballad is completed only in hemistich 20 .

This delay might appear to be a case like those proposed by Ruth House Webber in her 1979 article "Ballad Openings: Narrative and Formal Function," in which an ambivalent opening could serve as a device to pique the curiosity of the audience, to make the listeners pay closer attention. The Evil Spell, after all, is a ballad in its own right, whose outcome may be either marriage or death. There are thus at least three directions in which such a beginning might go, and it is not unreasonable to postulate that an audience might listen carefully to discover which one will be chosen.

For contextual reasons I doubt that any such suspense was generated during Dona Conceição's performance. Part of the 
appeal of traveling storytellers and singers was undoubtedly novelty. In such cases a ballad opening like that of the Evil Spell might indeed generate suspense. Familiar repetitions by accomplished performers were also appreciated, however, and the variant under discussion clearly falls into that class. The ballad performed by Dona Conceição was recognized as being the rendering of a recently deceased local storyteller named Benedito Duarte. Only if Benedito Duarte knew more than one ballad with this same beginning could any doubt as to its ending arise. More likely he took advantage of the ambiguous Evil Spell opening to exercise a ribald sense of humor, with no thought of creating narrative tension. The situation as it is presented here is altogether too lighthearted to lead credibly to tragedy for the lovers, particularly in a ballad tradition like the Luso-Brazilian in which young love, even erring young love, is more often exalted than punished.

If it does not create suspense, however, the delay in mentioning the name of the man responsible for Dona Branca's condition does have the effect of focusing almost half the ballad on the central struggle between the father and his daughter. Their conflict is further stressed in the text by the alternating "filha," "pai," "filha," "pai," at places of emphasis in the first two stanzas ( $-\mathrm{O}$ que tendes, minha filha, . . .; -Não é nada, senhor pai ...) subsequently compressed into the initial "filha" and final "pai" of hemistich 9 ( - Filha que faz isso ao pai ...), repeated in hemistich 13.

The verb form "mandava" in hemistich 19, though strictly speaking ungrammatical in this context, is characteristic of colloquial speech, not limited to Espírito Santo or to any socio-economic group. In informal conversation the imperfect tense is almost always used following an imperfect subjunctive "if" clause, in preference to the grammatically correct conditional.

In an aside, which may have been directed specifically to me, Dona Conceição explains the sudden appearance of Carlos de Montevar. To her he is an ordinary fellow, a "rapaz " The old story has been recast in local contemporary idiom. Claros' sixteenth-century nobility, like that of his lover, has been forgotten.

"Aí foi, apareceu o demônio. Aí foi, falou assim:

(So the demon appeared. So he went and said thus:)

22 - Dona, faça a carta, que eu mesmo vou levar. 
24 Viagem de quinze dias eu tiro só num jantar."

(Lady, make the letter. I'll take it myself.

A fifteen-day trip I'll make in the time it takes to eat dinner.)

The first hemistich of this stanza is curious because it is missing two syllables. The deficiency could easily be remedied by having the speaker address Dona Branca as "Minha dona," just as Claros in the first hemistich of the last stanza addresses "Meus senhores." I suspect this was not done here because the speaker is a demon in whose mouth the courteous formula "My lady" might be taken literally. At the minor expense of two syllables she is kept properly obsequious and safely distant from the young woman, who must not be suspected of seriously trafficking with infernal powers. His form of address parallels that of the disguised Claros in hemistichs 37 and 41 (-Dona, me dê um beijo/abraco ... .), who must also not be allowed to get too close. But the function of the formal address in the second case is different. It establishes an ironically comic contrast between the friar's very proper language and his very improper propositions.

Though a messenger who can inform Claros of his lover's peril is indispensable in Count Claros in Monk's Attire, the identity of the messenger varies greatly. In the Peninsular tradition of the ballad the messenger may be a relative, a servant, a bird or an angel. In the Brazilian tradition it is sometimes a demon. When I asked Dona Conceição why a demon suddenly appeared to serve as Dona Branca's messenger, she merely laughed and said that was the way it was. Since Dona Branca is no longer, as on the Iberian Peninsula, the daughter of a count, calling on a servant, though possible, is not specifically supported by her situation. The elaborate family background that justifies the predominance of the brother or cousin messenger in certain Portuguese variants is absent. As far as people in the region of Conceição da Barra were concerned, a demon would be at least as likely a messenger as any, a service requiring fast travel being precisely the sort of task a demon would be capable of performing. Dona Conceição and her audience live in a world inhabited by spirits, and they are familiar with their behavior and powers. The boast in the third and fourth hemistichs of the stanza is to be taken literally. 
"Aí ela foi, fez a carta, entregou a êle, falou assim:

(So she went and made the letter, gave it to him, and said thus:)

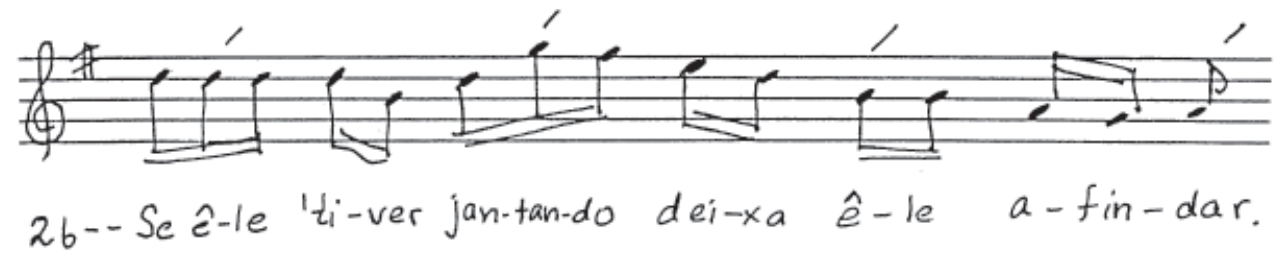

(If he's having dinner let him finish)

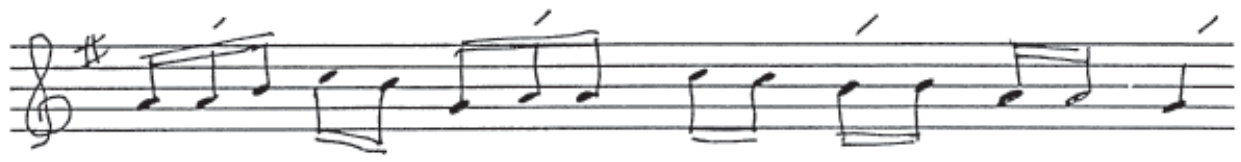

2c-. Se $\hat{e}$-le 'ti-ver dor-min-do dei-xa $\hat{e}$-le a-cor-dar.

(If he's sleeping let him wake up)

Instructions, frequent in the Portuguese variants of Count Claros in Monk's Attire when the woman addresses a young brother or cousin, are vestigial in the Brazilian tradition, where they appear only but not always when the messenger is supernatural, whether angel or demon. The complex social and family context that justifies instructing a young brother or cousin in the etiquette of approaching a count has not survived transmission to the ex-colony.

"Afindar" is a nonstandard form of "findar" It probably appears here by analogy with its rhyming word "acordar" The added syllable, by extending the first line and making it exactly parallel to the second, serves a poetic purpose.

The musical transcription of this stanza illustrates a partnership between musical and literary meter. Since Hispanic ballad meter requires phrases whose penultimate syllable is stressed to have eight syllables and those whose final syllable is stressed to have seven, it is clear that in a literary ballad these lines would be lacking syllables. If we follow the customary practice of synaloepha, the first and third hemistichs contain an insufficient seven syllables each, the second and fourth a severely deficient five. As sung, however, each syllable receives its own note. Hemistichs 25 and 27 are properly awarded eight sung beats, 26 and 28 are awarded seven. The music expands the verse.

Throughout this variant the relationship between syllable and note is almost uniformly one to one. Dona Conceição occasionally 
elides or apocopates words (as, for example, "iss' ao pai" in hemistichs 9 and 13). But apocopation in such contexts is characteristic of everyday speech. Equally, her omission of the first syllables of estás and estiver is consecrated by nearly universal usage. Dona Conceição reduces the word para to pa in hemistichs 40 and 42, but nobody says para in normal conversation. More noticeable is her pronouncing the entire word in the final hemistich of the ballad ("para seu pai se queimar"), where she needs both its syllables to fill the line. On the whole Dona Conceição tends to give words their full syllabic value.

"Aí quando chegou lá, chamou, disse assim:

(So when he arrived there he called and said thus:)

30 - Abr' aqui portas de vidro, janelas de Montevar,

32 que aqui tem uma carta que Dona Branca mandar. - "

(Open the glass doors, the windows of Montevar,

because there is a letter here which Dona Branca sent.)

[Seu Antero: E-e-i-i-i. ... .]

The implied grandeur of Claros' mansion is one of the two remaining traces of his original nobility. The other is the dom preceding his name in hemistichs 39 and 43 ("boca/corpo que dom Carlos beija/ abraça"). Though every mature woman is called dona in contemporary Brazil, dom has been almost entirely replaced by seu, a contraction of senhor. The nobility of the characters is vestigial in the Brazilian tradition of Count Claros in Monk's Attire. It has been retained to a greater degree in the Brazilian Count Claros and the Princess tradition for internal reasons to be discussed below.

The infinitive "mandar," used instead of "mandou" in hemistich 32 , marks the third concession of grammatical rules to the higher-ranked demands of rhyme.

"Aí êle pegou a carta; aí êle falou assim:

(So he took the letter; so he said thus:)

34 Quando leu esta cartinha se pôs logo a chorar.

36 Vestiu-se em traje de padre; coroa mandou botar."

(When he read this little letter he began to cry.

He dressed as a priest; he had a crown put on.)

This is the only verse segment of the ballad that is not dialogue. It is prefaced, however, with the same formula announcing dialogue that introduces the other segments. The error underlines the formulaic character of the prose intercalations. 
The "esta" of the stanza's first hemistich suggests unexpected immediacy. It is as if the singer were holding the letter in her hand. Dona Conceição seems briefly to merge her own perspective with the otherwise distanced narrative. The very Brazilian diminutive "cartinha" contrasts to the archaic tone of most of the rest of the stanza. The construction in the second hemistich, "se pôs a ...," is unusually formal, as is the "vestiu-se" of the third hemistich. Though accurate in terms of grammatical rules, "vestiu-se" is a departure from the colloquial tone that characterizes the rest of the variant. Contemporary vernacular rarely employs the reflexive pronoun with this verb. Just as "esta cartinha" of hemistich 34 abruptly brings the ballad into our midst, the rest of the stanza abruptly removes it. At this moment of conflict between tradition and innovation, tradition has imposed itself.

Hemistich 36 is a good example of a clash between tradition and innovation whose resolution is less than satisfactory. Dona Conceição's "coroa mandou botar" seems to be an attempt to reinterpret an action whose significance has been lost. Forms of the phrase raspar coroa meaning "to tonsure" appear frequently in the Brazilian Count Claros in Monk's Attire. But someone involved in the transmission of this particular variant apparently did not understand what it meant to shave one's crown, and chose to replace it with the more intelligible "put on a crown." Unfortunately, the result in the context of the narrative is nonsense.

It is significant that the rendering's only narrative verse segment should include both its most archaic forms of expression and its least successful innovation. Narrative verse has tended to disappear from Brazilian ballad tradition, being either omitted altogether or replaced by prose. The ability to create and innovate, even to recall, that can be observed in dialogue segments does not seem to extend to narrative verse.

"Aí quando êle chegou, ela estava chorando. Aí êle foi, falou assim:

(So when he arrived she was crying. So he went and said thus:) 
40 - Boca que dom Carlos beija não é pa' padre beijar.

(The mouth that don Carlos kisses is not for priests to kiss.)

Ela não conheceu mais êle.

(She didn't know him any more.)

[Seu Antero laughs.]

"Aí êle foi, falou assim:

(So he went and said thus:)

42 - Dona, me dê um abraço, qu' eu não the deixo matar.

(Lady, give me a hug, and I won't let them kill you.)

Aí ela falou:

(So she said:)

44 -Corpo que dom Carl' abraça não é pa' padre abraçar “

(The body that don Carlos hugs is not for priests to hug.)

[Seu Antero: "Viu!" (See!) Unintelligible comments and murmurs from the audience, now entirely involved in the story on the side of Dona Branca.]

Claros' journey is another narrative segment that apparently has not survived in the Brazilian Count Claros in Monk's Attire. A feeling that some preparation for the temptation scene is lacking may have led Dona Conceição to explain in an aside that Dona Branca did not recognize her lover. Clarification is particularly necessary since the detail of the crown, which originally helped describe the disguise, in its form here actually subverts it.

The variant returns to dialogue in hemistichs $37-44$, divided as at the beginning of the ballad into challenges and ripostes. Dona Branca shows as much wit and presence of mind in fending off her disguised lover as she did in answering her father.

These stanzas are entirely traditional. The test is the heart of Count Claros in Monk's Attire, and thus is much less open to significant alteration than any other segment. In contrast to its end, the beginning of this variant has been doubly altered. The Evil Spell opening has itself been modified by a singer about whose name we may only speculate. Nevertheless, the rendering is a well-constructed unit. The father's questions parallel the lover's propositions. And Dona Branca's second set of responses, as compared to the first, concisely demonstrates that she has grown into assuming responsibility for her actions. The test in Count Claros in Monk's Attire may comprise from one to three challenges. Its doubling here does not indicate forgetfulness or structural weakness. On the contrary, by exactly paralleling the doubled questions at the beginning, it reinforces the melding of the Evil 
Spell and the Count Claros into a single ballad.

"Aí êle foi, falou assim:

(So he went and said thus:)

46 - Meus senhores, me desculpem. Todos queiram desculpar;

48 A fogueira fica feita para seu pai se queimar."

(Gentlemen, excuse me. All of you excuse me please.

The pyre has been made for her father to be burned.)

Such violent revenge is unusual but not unique among published Brazilian variants of Count Claros in Monk's Attire. In published Peninsular texts Claros' revenge is limited to his carrying off his lover without her father's consent, sometimes daring any of her relatives to try to stop him, sometimes remarking ironically on the "dowry" the father planned to give his daughter, occasionally consigning dogs or old women to the flames so as not to waste a perfectly good pyre. In Dona Conceição's variant the father is explicitly the guilty party. Claros, with extreme politeness begging the pardon of those who have gathered to watch the execution, suggests that the fire can be used to burn the father. The narrator agrees:

"A fogueira estava feita para ela. O pai

dela $-p \tilde{a} !$ - caiu dentro da fogueira, morreu queimado.

(The fire was made for her. Her father-pow! - fell in the fire and burned to death.)

[Seu Antero: "Ei!"]

E êle casou corn ela. Estão vivendo até hoje."

(And he married her. They're still living today.)

[Seu Antero (laughing): “Aí, meu Deus do céu!”] (Oh, my God in heaven!) Unintelligible comments and laughter from the rest of the audience.

[Seu Antero: "Essa estória é muito bonita. . . . Boa, boa . . .

E boa essa estória.’]

(That story is very pretty. .. . Good, good ... It's good, that story.)

This gruesome ending was told with a smile and received with approving laughter. The $p \tilde{a}$ represents the sound of the father falling into the fire. From the perspective of total identification with the lovers his impromptu immolation is morally, socially, and poetically justified. 
The terminating "estão vivendo até hoje" is similar to the conventional tale ending, "and they lived happily ever after." It is more immediate, however. The narrator specifically brings the end of the story into the present, for a moment locating these characters in everyday reality. This final sentence could serve as a metaphor for the oral traditional ballad itself, a medieval creation which through generations of transmission is still living today.

\section{Count Claros and the Princess: Claralinda}

Dona Preta, whose real name is Maria Eulália de Jesus, was sixty years old when I met her in 1978. Born and brought up in rural southern Bahia, she had traveled extensively within the region comprising southern Bahia, northeastern Minas Gerais, and northern Espírito Santo. She moved to Conceição da Barra while I was there, and established a terreiro, a center for Afro-Catholic ritual as practiced in her native Bahia, known as candomblé.

By profession Dona Preta was a mãe-de-santo, a medium. During the weekly sessions at her terreiro spirits were called down through singing, dancing, and the beating of drums to possess her and her followers. Part of her office, for which, unlike the candomble sessions, she was paid, was to seek the occult sources of people's spiritual, emotional, or financial difficulties, and to perform services to right wrongs. Dona Preta insisted she worked only toward good ends; unlike others of her profession, she claimed to shun the powers of evil, though she knew how to deal with them when they appeared unsummoned. She also sold cloth and women's clothes her adult children bought cheaply in São Paulo and brought to Conceição da Barra. Dona Preta's prices were high, but her followers paid them more or less willingly, partly to help her make a living and partly to gain and retain her good graces.

I first recorded Dona Preta at one of her candomblé sessions, and I began to get to know her when I took the tape to the center a few days later for her to hear. I was told Dona Preta was a good storyteller, and could well believe it, for her dominating and dramatic manner transformed even the most banal of conversations into a performance; but when I approached her on the subject of telling me stories she demurred. In Bahia, she said, people had gathered often to tell stories, but she had not told a story in years. Alienated from her natural storytelling context, she 
had lost all interest in the pastime. I never asked her specifically about ballads, since she clearly lived and worked more in the Afro-Brazilian than in the Luso-Brazilian tradition.

I continued to visit Dona Preta with friends who had become involved in her spiritist center. It was after I had done a few favors for her-disinterested favors because I had abandoned hope that she might perform for me - that she suddenly volunteered to tell some stories for me to record. At her invitation I took my tape recorder to the terreiro one Sunday afternoon. The room looked strangely small and bare without the usual crowd of magnificently attired dancers. The floor was clear, but the benches that lined the walls began to be occupied by others who had been invited or had dropped in to see what was going on.

Dona Preta first invited my good friend Niva and me to come into the tiny kitchen adjoining the center. There she offered us coffee and sweet bread. When we had eaten and drunk all we wanted, we returned to the main room. Dona Preta seated herself on a nearby chair while I set up the tape recorder on a small table she had provided. She told three stories for me that afternoon. Another woman and a man contributed with one story apiece.

Dona Preta later told me she had learned most of her stories and ballads from a man she called her stepfather. He did not live with her family, but spent most of his time "up north" - she could not tell me exactly where. Whenever he returned to Bahia families would vie for his presence, for he was an accomplished storyteller and singer. In return for food and hospitality, and the pleasure of telling a good story to an appreciative audience, he would spend the night entertaining. He was not paid for these evenings. Dona Preta's stepfather was a traveler, and thus a diffuser of stories and songs. Dona Preta recalled a few of these for me, including the Donzela guerreira (The Warrior Maiden). I am certain she had known many more, for, unable to read, she had a prodigious memory and the true traditional performer's love of telling a good tale.

To my astonishment the first story Dona Preta told was a variant of Conde Claros y la infanta (Count Claros and the Princess). She began in prose:

Disse que era um reis que tinha uma filha. Bom ... Como êle era . .. era um reis, muito rico, né? Tinha uma filha. Bem ... essa filha já vivia quase 
escondida.

Então tinha um moço. Também não era gente muito ruim, não, gente bem de vida também, mas não era reis, né? Então intentou de casar com essa . . . com essa dona. Conversaram namoros escondidos [smiling] d'aqui, d'ali, namoros escondidos.

Quando era um dia êles trataram, foram para a praia. Quando êles estão lá conversando, batendo um papo numa bancada, vai passando . . . um sujeito trabalhava p'r'o reis, né? Era de lá. Era acho que empregado lá da fazenda, da casa. Aí vai passando ... [emphatically] que quando ela avistou o reis . . quando ela avistou . . . avistou o sujeito longe, ela levantou e ficou logo em pé. Aí quando êle vem passando pa-pa-pa . . . aí ela gritou ... [long pause] . . Hm . . .

Aí ela falou assim:

(It was said there was a king who had a daughter. Well ... Since he was . . . he was a king, very rich, right? He had a daughter. Well . . . that daughter lived almost hidden away.

Then there was a young man. He wasn't very poor. He was well off, too. But he wasn't a king, right? So he tried to marry that . . . that lady. They got together in secret to talk about love. Here, there. Secret love talks.

One day they decided, they went to the beach. While they are there talking, having a talk on a long bench, here comes . . . a fellow who worked for the king, right? He was from there. He was, I think, an employee of the ranch, of the house. So here he comes ... and when she saw the king ... when she saw. . . she saw the fellow far away, she got up and stood. So when he comes by pa-pa-pa-pa-pa... she yelled ... . Hm...

Then she spoke thus:)

Dona Preta begins with the same formula as does Dona Conceição. She describes at greater length the relationship between the very rich king and his nubile daughter, whom he keeps almost hidden. After establishing this inherently unstable narrative 
situation, she introduces the suitor. Typical of the Brazilian tradition of Count Claros and the Princess, nothing remains of Claros' amorous anguish, so greatly emphasized in the sixteenth-century Spanish text of this ballad. His nobility has been abandoned as well. Whereas Dona Conceição's Claros was a rapaz, Dona Preta's is a moço. There is no significant difference between the terms; Claros is merely a young man. For cogent narrative reasons he has not, however, been demoted to servant, peasant, or fisherman. If Claros worked for the princess or her father, the tale type suggested would be the ballad of Gerineldo, which treats the particular difficulties raised by sexual congress between mistress and servant. If he were a peasant or fisherman, the tale type, very popular in the region of Conceição da Barra, would be that of the young man who wins a princess by wit and resourcefulness despite his poverty and humble lineage. Neither of these tale types corresponds to Count Claros and the Princess. If Dona Preta's protagonist has lost his medieval pedigree, he nonetheless retains the substantial fortune that in contemporary Brazil puts him in a social class from which he may aspire to woo a princess despite her father's objections.

The location of the tryst may be an innovation by Dona Preta. The archaic pleasance (vergel), occasionally modernized in Brazil into a garden (jardim), is inappropriate here since the king lives on a ranch. Its replacement by the beach may have been determined by local characteristics. We were living in a town very much dominated by the sea, whose beach was far more hospitable to dalliance than its insectinfested tropical forest.

Dona Preta's description of what the two young people were doing at the beach is no more than mildly suggestive. The young man's intentions are explicitly honorable. Though conversas are often a colloquial euphemism for sexual relations (and Dona Preta's smile at "namoros escondidos" hints that something is left unspecified), there is nothing in the narrator's tone when the two are discovered that might force a double meaning. On the contrary, her appositive "batendo um papo" seems designed to defuse the sexual charge of this sensitive moment. Unlike in some other variants of Count Claros and the Princess, the two are not caught in flagrante. The princess sees the approaching servant and stands while he is still far off. Then, as he is passing, she calls to him.

Though I have transcribed all Dona Preta's hesitations and 
repetitions as well as her minor errors and their rectifications, it should be remembered that such mistakes are hardly perceived in an oral performance. I had to listen attentively several times to the recording before I could represent them faithfully. What is perceived is the informal tone of the telling. This prose introduction-divided into a narrative background recounted in the past tense and a narrative present describing the meeting of the lovers with the passerby - is typical of Dona Preta's storytelling style. Highly colloquial, pronounced in her heavy Bahian accent, it contains the interjections, "bom . . .," "bem ...," as well as pauses for dramatic effect and the question tag "né?" at the end of sentences, designed to involve the audience. Dona Preta, apparently uncertain of the passerby's identity, enters the narrative with the first person "I," a device that lends the impression of authenticity and immediacy to the telling.

The ranch, like the beach, is a Brazilian feature. Locally, the authority of the rich rancher would be the palpable analogue of that of a remote king. King and rich rancher have here been merged into a single powerful figure. But if a rancher can stand in for a king, we might reasonably wonder why the father's royalty has been retained at all. Claros' nobility in both Count Claros and the Princess and Count Claros in Monk's Attire has gone the way of his lover's virginity; and in the Brazilian Count Claros in Monk's Attire the young woman's father (who in contemporary Peninsular variants is usually a count) has lost his nobility as well.

There are both narrative and social reasons for the retention of the father's royalty in Count Claros and the Princess. In narrative terms Dona Preta's variant has been subsumed into the group of ballads and tales that open with the father's imprisoning his daughter to prohibit her contact with men. Often the man who performs such an act is a king. In contrast, the Evil Spell opening, which has become the most common beginning of the Brazilian tradition of Count Claros in Monk's Attire, is neutral regarding the social status of the father.

Further, royalty, which has never been essential in Count Claros in Monk's Attire, is indispensable in Count Claros and the Princess. The significant difference in this respect between the two versions of the Count Claros story is that the father in Count Claros in Monk's Attire threatens to kill his daughter, whereas the father in Count Claros and the Princess threatens to kill her lover, and often has the informer killed. Only a person of legitimate 
social authority may order the execution of another, unless (Count Claros in Monk's Attire seems to be saying) that other is his own daughter. The credibility of Count Claros in Monk's Attire depends on the belief that any father in questions of honor has life-and-death authority over his own daughter. It is important to note, however, that Count Claros in Monk's Attire does not support this belief. Despite the notorious variability characteristic of any oral traditional ballad throughout its secular career, the young woman in Count Claros in Monk's Attire is never actually burned, and some variants (including Dona Conceição's) go so far as to condemn her father to the flames. Thus, the real moral to be drawn from Count Claros in Monk's Attire is that there are laws higher than those of the honor code. According to them the father's assumption of power belonging only to God is a potentially mortal illusion. Count Claros and the Princess does not deal with such questions. Kingship must be retained because the social and political authority it affords is required for the unfolding of the narrative.

Dona Preta, unlike Dona Conceição, supported her performance by gestures. Her onomatopoeiac $p a-p a-p a-p a-p a$ was accompanied by chopping hand movements to indicate the passerby's rapid pace. This attracted the attention of the listeners, who in this recital were also spectators.

After announcing that the princess called out to the passerby, Dona Preta paused and stared at the floor. Even more pointedly than Dona Conceição she seemed to be contemplating the imminent switch to a musical mode. Perhaps she was silently recalling the tune; perhaps she was pausing for effect. The final prose line-whose verb, unlike Dona Conceição's at the parallel juncture of her performance, indicates speech-leads into the singing after only a short pause.

As in Dona Conceição's variant, prose segments introduce changing speakers. "Aí ela falou," and "aí éle disse," have become part of the ballad. Dona Preta's delivery was more calculated and dramatic than that of Dona Conceição; her prose intercalations were slightly more varied. Greater conscious control over the nuances of presentation is to be expected from a singer whose profession involves performance, even if her usual sphere is not the oral traditional ballad. 
$=96$ (rubato)

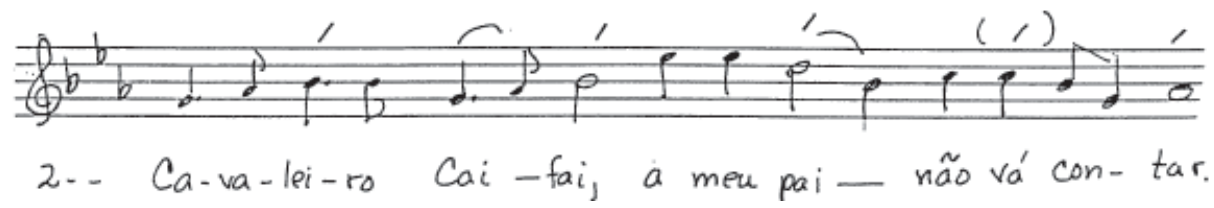

(Gentleman Caifai, don't go tell my father.)

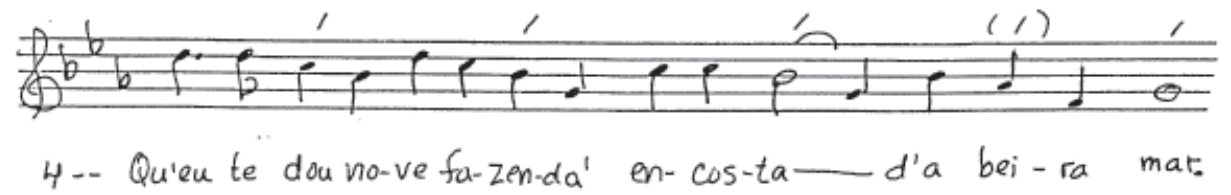

(I'll give you nine ranches along the seacoast.)

The first hemistich is an abrupt break from Dona Preta's informal spoken style. The princess uses the peculiar, and to my knowledge unique, address "Cavaleiro" to call the passerby. In most Brazilian variants of this ballad, as in much of the Peninsular tradition, the passerby is a hunter, and is addressed as "Caçador."

"Caifai" is also anomalous. Since I have discussed its significance in my article "Notes on Creativity," I will merely observe here that the name carries connotations of betrayal, which intimate from the outset that the princess is wasting her time trying to convince him not to tell on her. Following the Count Claros tradition, however, she makes three offers in exchange for his silence.

Offering land seems to be rare in the Brazilian tradition of this ballad. In the only published variant to offer land (Lima 1977:151-53), the princess tries to buy the passerby's silence with lands in France. Dona Preta's bribe is more Brazilian and far more vivid: nine ranches, which, to increase their value, are located along the coast. The number nine is fitting in this variant sung by a woman accustomed to dealing with mystical numbers. The uma that would fit both metrical and concordance schemes perhaps does not convey with sufficient force either the princess's wealth or her desperation. Tres does not have sufficient syllables to fill the line; and sete, though it would provide internal rhyme with fazenda, is less sonorous than none with its nasal and voiced consonants. 
Alliteration and internal rhyme in this stanza and throughout the rendering suggest that Dona Preta is unusually sensitive to sounds. The labio-dental voiced/unvoiced fricative sequence v...f of "nove fazenda" replicates that of "Cavaleiro Caifai," whose first syllables are themselves nearly identical. In "nove fazenda" the v...f sequence is pleasingly framed by two sonorant "n's." I am not claiming that Dona Preta constructed her ballad on the level of individual sounds. But I do believe that certain sound sequences would prove more satisfying than others to her practiced ear. Dona Preta, as mãe-de-santo, was a composer as well as a singer. Like the spirits her music summoned, she was highly attuned to the nuances of sounds.

Dona Preta distinctly sang "nove fazenda." The lack of noun/ adjective concordance presents no problem to her. Omission of the final " $\mathrm{s}$ " that in grammatically correct speech indicates plurality is characteristic of the vernacular, the plural number alone being considered sufficient. Absence of the "s" of "encostada" in the final hemistich of this stanza is, moreover, functional, for its presence would create syllabic excess. Though both Dona Preta and Dona Conceição are tolerant of hemistichs that lack syllables, neither ever exceeds the correct number.

Dona Preta's tune, which actually began and ended on B-flat below middle $\mathrm{C}$, is slower, more chant-like than Dona Conceição's. The first phrase ("Cavaleiro Caifai") is divided musically as well as verbally into two parts based on nearly repeated ascending major thirds. The second phrase begins a fourth above the last note of the first phrase. This is the highest pitch of the tune, to which it does not return.It is an anacrusis, corresponding neither to musical nor to verbal stress. Nonetheless it is an important moment, where the princess begins her plea and where in reply the passerby emphatically rejects it.

The functional importance of the verb "contar" ("to tell") in the second phrase is underlined by its position at the mid-cadence, the extended point of greatest musical tension. The significance of the phrase's other important word, "pai," is emphasized musically through the extension of the word's single syllable into three beats and two pitches. No comparable phenomenon was observed in Dona Conceição's almost conversational rendering, where each syllable received a single beat and pitch. The major third is the principal interval of the second phrase as it was of the first. But it is now descending rather than ascending. 
The third phrase, though on different pitches, essentially repeats the contour of the second. The fourth phrase consists basically of four steps descending to the final. Yet it, too, is patterned in descending thirds. The final of the melody is not the tonic of its implied major scale, but rather the third of that scale. The tonic itself is never touched, though its octave serves as the initial pitch of the second phrase. Absence of the tonic reinforces the chantlike, continuous quality of the melody, with its confined yet restless alternation between ascending and descending notes at the interval of a third. The pattern of the music mirrors the movement of the ballad's first segment: back and forth, back and forth, back and forth between the princess and the passerby.

In terms of rhythm Dona Preta's rendering is more regular than Dona Conceição's. The phrases, however, are of different lengths. Phrases 1 and 3 have eight beats each and two principal pulses, which fall on their third and seventh beats. The second and fourth phrases are longer than the first and third, and seem to have a secondary pulse as well as two principal musical pulses. Musical pulses correspond to verbal stresses in stanzas $1,3,5,7$, and 9. They differ in 2, 4, 6, and 8 .

"Aí êle falou assim:

(So he said thus:)

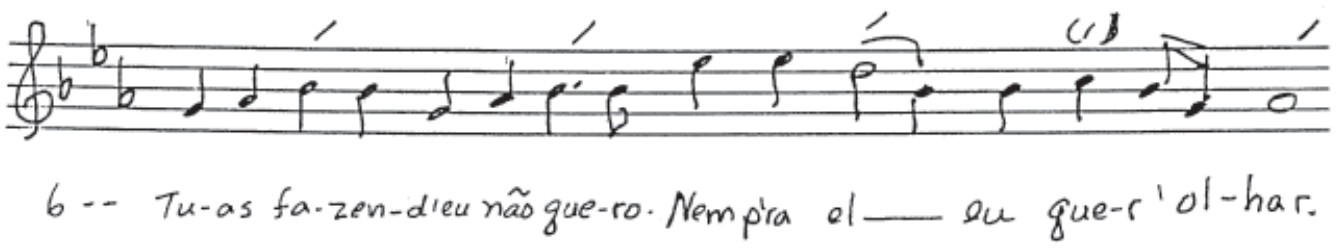

(Your ranches I don't want. I don't even want to look at them.)

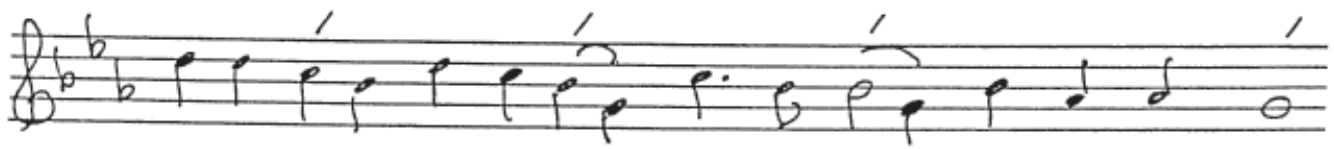

8.- Se eu forcon-tar ao rei- mui-to mais- e' de gan-har.

(If I go tell the king I will gain much more.)

When Dona Preta is speaking she uses the vernacular pronunciation "rein" for the word she pronounces "rei" in the sung portions of the ballad. In this instance sung verse resists the inroads of colloquial alteration.

Again Dona Preta omits the final "s" of "fazendas," the 
plural having been adequately represented by "tuas "She is then able, as in the first stanza, to drop the now-final unstressed "a," thus avoiding an excess syllable. Apocopation and elision, characteristic of this variant, will be represented in the transcriptions from now on, but not mentioned in the text. Together with the slow, repetitive tune, the tendency to join words gives this variant a flowing sound that may be contrasted with the more staccato rendering sung by Dona Conceição.

In view of the predominance of vowel elision in this performance, the lack of it in the third hemistich of this stanza ("Se eu for contar ao rei") is worthy of note. In the corresponding hemistich of the first stanza, the first two syllables comprising three words ("qu'eu to") established the principal adversaries, the princess assuming the role of subject and the passerby that of object. In this stanza the roles are reversed. The action pivots on the potential betrayal contemplated in the third hemistich of the stanza. This hemistich names the individuals involved: the potential informer ("P in this stanza) and the king. Focus on the former is sharpened by the avoidance of vowel elision, while emphasis on the latter is provided by its location at the end of the hemistich and reinforced by the music: two pitches for a single syllable.

With the exception of hemistich 19 (a special case to be discussed below), hemistichs 7, 15, and 23 ("Se eu for contar ao rei") are the only ones in this position to have fewer than eight syllables. Despite this, the music continues to have eight beats. The final word of the hemistich, "rei," like "pai" in the second hemistich of the first stanza, is awarded an extra beat and two pitches. "Pai" and "rei" are, of course, the same person seen from crucially different perspectives. The third hemistich of the second stanza, "Se eu for contar ao rei," is like a distorted echo of the second hemistich of the first stanza: "A meu pai não vá contar." As if to emphasize this, the music lingers over the word "rei" in the second stanza as it did over "pai" in the first.

Similarly, the music lingers lovingly over the word "mais" in the final hemistich of this stanza. Its three beats and two pitches follow the same pattern as the corresponding moment of the second hemistich. They thus constitute musical rhyme, whose significance can be seen when we return to the first stanza, specifically to the already-mentioned "pai" of its second hemistich. The words "pai" and "mais" are in assonance, which is supported by the musical 
rhyme. These two features in turn reinforce the fundamental unity of each pair of stanzas. Within each pair the princess's varying offer and the passerby's corresponding rejection of it are preceded by her unvarying plea and followed by his equally unvarying speculation that telling the king will be worth more to him than anything she can offer. Essentially unchanging lines framing each pair of stanzas define the principal conflict, which in this version of the Count Claros is not between the father and his daughter but rather between the princess and the informer:

Cavaleiro Caifai, a meu pai não vá (vai) contar

Se eu for contar ao rei muito mais hei (é) de ganhar.

"Aí ela falou:

(So she said:)

10 - Cavaleiro Caifai, a meu pai não vai contar;

12 Eu te dou minha sobrinha para você se casar “

(Gentleman Caifai, don't go tell my father.

I will give you my niece for you to marry.)

This is a traditional offer, not substantially different from Claros' sixteenth-century offer of his first cousin as wife. Dona Preta's rendering is, however, consistent with the tendency in the Brazilian tradition for the woman to take the initiative. Claros is certainly necessary in both versions of the Count Claros ballad, but in neither of them does he have a central role in the conflict.

When she needs the syllable to complete the hemistich, Dona Preta, like Dona Conceição, avoids her customary apocopation of the word para. The anomalous "você" in a context where the pronoun "tu" has been and will henceforth be employed seems also to be a means of fulfilling syllabic requirements.

Dona Preta in this stanza sings "vai" in the second hemistich instead of "vá." This contributes to the unusual amount of internal rhyme, alliteration, and near alliteration (indicated by italics) in an otherwise undistinguished stanza.

"Êle respondeu:

(He answered:)

14 -Sua sobrinh' eu não quero, nem p'ra el' eu quer'olhar;

16 Se eu for contar ao rei, muito mais é de ganhar."

(Your niece I don't want. I don't even want to look at her. If I go tell the king I will gain much more.) 
The second response parallels the first. "Sua" used here in place of the "tua" of the second stanza and the "teu" of the sixth may have been suggested by the "vocé" of hemistich 12 or the initial "s" sound of "sobrinha."

"Aí ela disse:

(Then she said:)

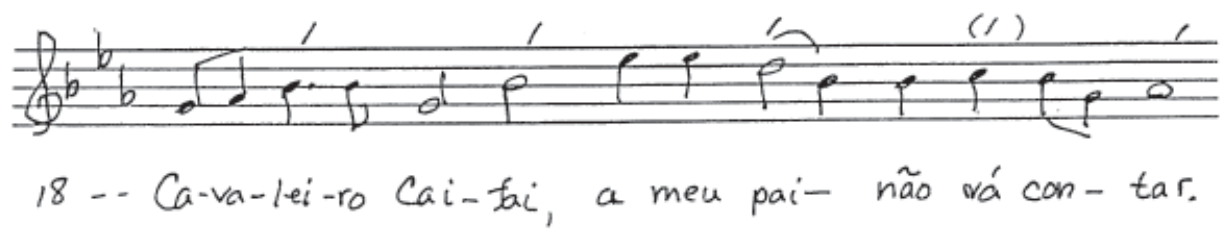

(Gentleman Caifai, don't go tell my father.)

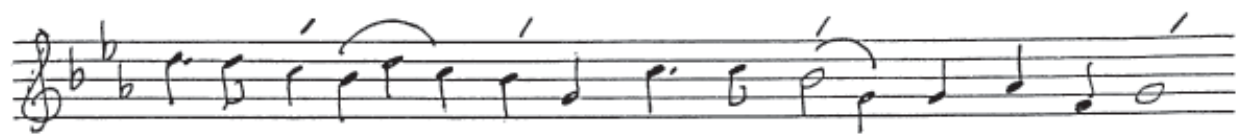

20-- Qu'ou te dou ou-róem pó en-quan-to po-ssa ca-rre-gar.

(I will give you gold dust. As much as you can carry.)

The arrangement of words and music underlines the seductiveness of this final offer. The first syllable of "ouro" is drawn out for two notes, and its second syllable is not dropped but rather pronounced and elided to the following word. If the third hemistich were recited it would have only six syllables (a mere five if "dou" were elided to "ouro"), while the fourth hemistich would have eight, an unacceptable number for a masculine rhyme. As sung, however, the third hemistich is immediately linked to the fourth by the device of singing the first syllable of "enquanto" on what is usually the final note of the preceding phrase. Music and words work together to form a line without the customary caesura. It is as if the princess did not want the passerby to have time to stop and think.

This is the culminating offer. In other Brazilian variants it typically takes the generic form "gold and silver." Dona Preta's image of "all the gold dust you can carry" is, in contrast, particularly vivid.

"Ele falou:"

(He said:)

22 - Nâo quero teu ouro em pó, nem p'ra el' eu quer' olhar; 
24 Se eu for contar ao rei, muito mais é de ganhar."

(I don't want your gold dust. I don't even want to look at it. If I go tell the king I will gain much more.)

But the greedy passerby wants still more. Just as the finality of the last offer was indicated by altered phrasing, the finality of the refusal is reinforcedbyachangeinthewordorderestablishedinthe preceding stanzas. The "não quero," previously located at the end of the first hemistich, is placed at the beginning. This emphatic refusal closes the tripartite series of offers and rejections, and the first section of the ballad.

\footnotetext{
Bom . . . Então ela . . . não pôde fazer mais nada, né? Saiu. Que ligeiro viajou, mais o moço também: "Vam' ‘bora p'ra lá!” E ele se mandou, pa-pa-pa-pa-pa-pa. Foi chegando lá, bateu palmas [claps hands] entrou aí, foi chegando, foi dizendo . . . :

(Well ... then she ... couldn't do anything else, could she? She left. And she traveled fast, with the young man, too: "Let's get going!" And he went in a hurry, pa-pa-pa-pa-pa-pa. He was arriving there. He clapped his hands. He went in. He was arriving, he was saying . . :")
}

Return to prose narrative underlines the closure of the first part of the ballad. Again in her conversational narrative style Dona Preta appeals to the audience to agree that the princess had done all she could. All three abandon the beach, racing to the palace. The informer is the fastest. The $p a-p a-p a-p a-p a-p a$, accompanied as at the beginning by a chopping hand gesture, again represents his rapid pace. In rural Brazil people clap their hands to attract the attention of those inside a house. Dona Preta accompanied the narration with the action. The final phrase of this segment, composed entirely of verbs of action and present participles, emphasizes the informer's haste. Waiting for nothing, he gains entrance to the palace, simultaneously approaching the king and speaking.

26 "-Deus salve, senh . . . doutor rei, sua coroa sagrada;

28 Que eu vi a dona Lira mai' dom Carl' a conversar."

(God save, Mr. . . . Doctor King, your sacred crown;

I saw Dona Lira talking with Don Carlos.)

The singer's almost involuntary intervention can be seen in the first hemistich of this stanza. In those Brazilian variants that 
have retained this segment in verse, the informer's address ranges from the highly formal to the relatively informal. The narrators of three variants published by Jackson da Silva Lima (1977) are content to have the informer address the king as "senhor rei," an address probably derived from reversal of the greeting "rei senhor" found in Portuguese variants and an early twentieth-century Brazilian text. "Senhor rei," however, is not quite equivalent to "rei senhor" in terms of respect. The English equivalent of the former, "Mr. king," is a far cry from the latter, "king (my) lord." The distinction between the two forms of address in Portuguese, though less glaring, seems to have distressed Dona Preta.

Dona Preta begins to have the informer greet the king as "senhor rei" Then suddenly she hesitates, evidently judging the greeting insufficiently respectful. Quickly searching her memory, and almost without breaking stride, she substitutes the more respectful "doutor" for the "senhor" her sense of fitness has rejected. The term doutor is often used in Brazil to address any man of higher social and economic rank than the speaker.

This correction, made on the spur of the moment, illustrates one way in which contemporary patterns may be inserted into archaic niches of the traditional ballad. Somewhere in the history of this variant an old form of address had been replaced by a modern form Dona Preta found inadequate. Unable to reinvent the original formula, she replaced the faulty formula with one that seemed better to her. Her replacement, based on her own experience, manifests a specific instance of the openness that allows ballads to survive in contemporary oral tradition.

Whereas Dona Conceição consistently altered word endings in order to accommodate them to the rhyme scheme, Dona Preta refuses to do so. Though the second syllable of "sagrada" in hemistichs 26 and 34 is elongated and the third barely touched, the entire word is pronounced clearly despite its lack of coherence with the -ar rhyme scheme of the rest of the ballad. Addressing the "coroa sagrada" of the king lends an archaic tone to the rendering, which is particularly striking after "doutor rei." For a moment the ballad reaches back centuries to the time when the literally sacred honor of a king, represented metonymically by his crown, could be sullied by the sexual misbehavior of his daughter.

In this stanza the denouncing word "conversar" takes on shades of the double meaning Dona Preta seemed to mitigate in the prose introduction. The "mais" of hemistich 28 is the typical 
vernacular replacement of "cam" in this context. Now that the ballad is nearly over we have the first mention of the protagonists" names. "Lira" and "Carl" are recognizably related to Claralinda (as she is called most frequently in the Portuguese Count Claros and the Princess tradition) and Claros. Here, as in Dona Conceição's rendering of Count Claros in Monk's Attire, calling Claros "dom” is a vestige of his former nobility.

"Aí o reis falou assim: (Then the king said thus:)

30 - Se tu me contass' oculto muito haveras de ganhar;

32 Como tu contou ao largo, you mandar te degolar."

(If you had told me in secret you would have gained a lot.

Since you told in public I am going to have you beheaded.)

It is clear that the informer is to be executed for the crime of indiscretion. The first two hemistichs indicate he was possibly right in thinking he would gain more by telling the king than by keeping the secret. The second two show that his telling in public has led to his downfall. This reasoning is typical of the kings in the Luso-Brazilian tradition of Count Claros and the Princess, where the informer, for his sins, has been elevated to the status of a major character.

The absence of subject/verb concordance in the first and third hemistichs is characteristic of popular speech. The second person singular verb form (retained in hemistich 30 in the archaic "haveras") has virtually been lost. The corresponding pronoun, $t u$, is occasionally used in everyday conversation, as it is here, with the third person singular verb form.

[Rapidly, and laughing throughout] Aí salta ese moço lá p'ra cima. Se viu lá p'ra cima. Pá! [claps hands once] os pescoço ... o pescoço "avoou" p'ra lá!

(So that fellow jumps way up in the air. He found himself way up in the air. Pow! His neck ... his neck flew that way!)

This climactic segment, despite being in prose, contains a substantial amount of repetition, and was recited rhythmically. The informer's come-uppance, related with laughter, reinforced by clapping, was greeted by smiles and nods from the audience.

Dona Preta's variant, like some Portuguese and all other known Brazilian variants of Count Claros and the Princess, has undergone significant structural change from the sixteenth-century 
version, which focuses on the lovers. The powerful moral and narrative motif of greed and its punishment has drawn Count Claros and the Princess into its orbit. This transformation of the ballad has assured its survival, in modified thematic form.

“Aí ela foi entrando [claps hands once] mais o noivo, né? . . . mais o rapaz. Aí ela falou:

(So she was coming in, with her fiancé, right? ... with the young man. Then she said:)

34 - Deus salve, meu pai rei, sua coroa sagrada;

36 Que dom Car'é meu marido, com ele hei eu é de casar."

(God save, my father king, your sacred crown;

Don Carlos is my husband. I have to marry him.)

The fourth hemistich seems to incorporate both "hei" and "é."

Nothing is said about punishing the lovers. In this variant, consistent with the contemporary Luso-Brazilian tradition of Count Claros and the Princess, the original transgression, though motivating the action, has ceased to pose an important problem. By the princess's single word, "marido," the young man is transformed from illicit lover into husband. Though hemistich 36 makes it clear that his status as husband is de facto rather than de jure, this potentially inflammatory statement provokes not a murmur of protest from the king. On the contrary, he is delighted to engineer a quick resolution of the dilemma posed by the informer's public proclamation of his shame:

Foi nada, não, minha gente. [laughing] Na mesma da hora . . . com éle fez a festa. Chamou o pai, chamou o juiz, casou . . . e as meninas [gesturing with her chin toward the kitchen] estão terminando de beber cafezinho no instante. Já foi o fim, o fim da festa.

(It was nothing, my friends. At that very moment . . . he made a celebration. He called the father, he called the judge, he got married ... and the girls are finishing drinking coffee right now. That was the end, the end of the party.)

Closing a story with a wedding or party where one fits the narrative is traditional, as is linking the party, and thereby the narrative itself, to the circumstances of the telling. I recorded a story from another woman in Conceição da Barra with a slightly different and more conventional form of the same ending. The 
party to which that tale's characters had adjourned had just ended, and the teller (who had attended) told me she was just bringing me a piece of cake when she slipped and fell and dropped it. Dona Preta's closing, like Dona Conceição's, but more vividly and specifically, brings the ballad into the present. She has modified the formula in accordance with the actual event. The girls to whom she referred in word and gesture were some of the members of her spiritist center who, just as she was finishing the ballad, were finishing what remained of the coffee and sweet bread Dona Preta had offered Niva and me before the session began.

Thus far, the discussion of Dona Preta's variant has followed segment by segment the narrative of the ballad. The structure of the ballad, however, merits a closer look. A very brief analysis of its superficial structure shows both dual and triple organization. Its nine stanzas are divided into two parts, the first part comprising six stanzas and the second three. The first part of the ballad moves slowly, back and forth between the princess and the passerby. There is no action, only talk. In contrast, each stanza of the rapidly moving second part describes or implies an action: betrayal, execution, marriage.

Further divisions may be perceived within the sections. The first six stanzas are divided by parallelism into three pairs, each comprising an offer and its rejection. This segment's primary disposition may thus be considered to be three times two. Another factor is introduced, however, by variation within the stanzas. The first two pairs vary minimally, only as much as is required by changing the offer. The greater variation of the culminating third pair sets it apart from the others. From the perspective of verbal parallelism the three pairs of stanzas may be divided into two plus one, a division that mirrors the organization of the ballad itself.

The three stanzas of the second part may also be divided into two plus one. The first stanza expresses the confrontation between the informer and the king, the second its resolution. The third compresses into four hemistichs the confrontation between the princess and her father and the resolution of the situation that has motivated the ballad. Yet the finality of this disposition is denied by the verbal parallelism between the first and third stanzas of the segment ("Deus salve [. . .] rei, sua coroa sagrada"), a parallelism that emphasizes the section's fundamental unity.

I do not mean to imply that anyone in Dona Preta's audience was counting stanzas, much less pondering their 
interrelationships. Nevertheless, dual and triple figures are so widespread within oral tradition that they may reasonably be considered fundamental organizing principles. The aesthetic value of such patterns lies in the satisfaction afforded when the completion of a series fulfills expectations raised by its beginning and sustained by its continuation.

The presence of overlapping patterns like those we have seen here adds another dimension to the variant. At one moment the ballad may be perceived to have a certain form. Then, looking from another angle, we see that it also has another. The ballad, like an optical illusion, may simultaneously incorporate distinct patterns. This capability, even if not consciously perceived, adds to its texture. A sung oral traditional ballad cannot be reduced to a mere chain of events. Organizing principles are at work on every level of its composition and performance. Narrative structure is expressed through superficial and verbal structures as informed by musical structure. Inconsistent interaction among the elements that comprise a traditional ballad traditionally performed creates a dense counterpoint that enriches its presentation.

The variants considered here, with all their flaws and successes, represent complete narrative structures convincingly performed. Every moment of each rendering manifests a resolution of the inevitable, indeed life-giving, conflict between tradition and actuality, just as each text manifests a given moment in the lifetime of the ballad. The oral traditional ballad is not a museum piece. In order to survive, it must be able to incorporate change on every level-structural, thematic, verbal, musical-without disintegrating. The variants examined here demonstrate this capacity. They provide specific examples of ballad survival through the interplay of retention and adaptation, evident in two captured instants of the Count Claros tradition.

Indiana University

Notes

\footnotetext{
${ }^{1}$ My fieldwork in Brazil was supported by a joint grant from the Fulbright/Hays Commission and the Social Science Research Council.

${ }^{2}$ Bibliographical information on this work and all others to which I refer can be found in the list of references at the end of the volume.
} 
${ }^{3}$ Both of these, and a third version of the "Count Claros" story, known as "Count Claros and the Emperor," can be found in Wolf and Hofmann's Primavera y flor de romances, nos. 190-92.

${ }^{4}$ See, for example, Katz 1972-75.

${ }^{5}$ Five months I spent collecting ballads in the province of León, Spain, were supported by a grant from the Council for International Exchange of Scholars and the Comité Conjunto Hispano-Norteamericano para la Cooperación Cultural y Educativa.

${ }^{6}$ Recordings of these ballads and the other material I recorded in Espírito Santo are available for consultation at the Instituto Nacional do Folclore, Rua do Catete, 179, Rio de Janeiro, RI, Brazil and the Archives of Traditional Music, Indiana University, Bloomington, IN, 47405 USA. 